\title{
Comparative study of labetalol and nifedipine in management of non- severe preeclampsia and its fetomaternal outcome
}

\author{
Delphine T. Rose, Jeyarani P.*
}

Department of Obstetrics and Gynecology, Thanjavur Medical College, Tamil Nadu, India

Received: 09 March 2019

Accepted: 02 April 2019

*Correspondence:

Dr. Jeyarani P.,

E-mail: jeyarajkumar06@gmail.com

Copyright: (c) the author(s), publisher and licensee Medip Academy. This is an open-access article distributed under the terms of the Creative Commons Attribution Non-Commercial License, which permits unrestricted non-commercial use, distribution, and reproduction in any medium, provided the original work is properly cited.

\begin{abstract}
Background: In developed countries, 16 percent of maternal deaths were attributed to hypertensive disorders. Of hypertensive disorders, the preeclampsia syndrome, either alone or superimposed on chronic hypertension, is the most dangerous. The incidence of preeclampsia in nulliparous populations ranged from 3 to 10 percent.

Methods: The present study was conducted at Government Raja Mirasudhar Hospital, Thanjavur Medical College, Thanjavur, Tamil Nadu, India from October 2017 to October 2018. The study consisted of 100 antenatal women with non-severe preeclampsia. The efficacy of labetalol verses nifedipine in its management was studied along with the fetomaternal outcome.

Results: In this study, in the labetalol and in the nifedipine groups adequate control of blood pressure was achieved. However, labetalol was well tolerated by our women without much side effects.

Conclusions: The present study indicates both labetalol and nifedipine are equally efficacious in the control of hypertension in non-severe preeclampsia. Pathology of the disease was not altered significantly in both the groups. There was no significant difference in the neonatal outcome between the two groups.
\end{abstract}

Keywords: Hypertension, Labetalol, Non-severe preeclampsia, Nifedipine

\section{INTRODUCTION}

Preeclampsia is best described as a pregnancy-specific syndrome that can affect virtually every organ system. In addition, it heralds a higher incidence of cardiovascular disease later in life. ${ }^{1}$ Preeclampsia (PE) is a clinical entity characterized by either the new onset of hypertension and proteinuria or end organ damage after 20 weeks of gestation. It is one of the major pregnancy-related hypertensive disorders. The clinical manifestations are triggered by mild to severe microangiopathy of target organs, including the brain, liver, kidney, and placenta. ${ }^{2}$

In developed countries, 16 percent of maternal deaths were attributed to hypertensive disorders. Of hypertensive disorders, the preeclampsia syndrome, either alone or superimposed on chronic hypertension, is the most dangerous. The incidence of preeclampsia in nulliparous populations ranged from 3 to 10 percent. ${ }^{1}$ The markers like blood pressure, protienuria, presence of imminent symptoms, liver enzymes, platelet count, creatinine value are used to classify preeclampsia syndrome severity as severe and non-severe.

Potential maternal complications of preeclampsia include pulmonary edema, cerebral haemorrhage, hepatic failure, renal failure, and even death. Potential fetal complications are caused by placental hypoperfusion or the need for preterm delivery. ${ }^{2}$

The basic management objectives for any pregnancy complicated by preeclampsia are termination of 
pregnancy with the least possible trauma to mother and fetus, birth of a healthy newborn that subsequently thrives and complete restoration of health to the mother. Treating the hypertension does not alter the progress of the disease; however it has been shown that early treatment decreases not only the frequency of hypertensive crisis, but also the rate of neonatal complications. $^{3}$ Also if preeclampsia occur remote from term, pregnancy has to be continued till the stage wherein the fetal survival is good. During this period intensive monitoring of the mother and the fetus is done along with the use of antihypertensive drugs. Despite years of research, there remains a lack of consensus on what constitutes an ideal antihypertensive drug in pregnancy with minimum maternal and fetal side effects. This study compares the efficacy of labetalol and nifedipine in control of blood pressure in cases of non severe preeclampsia.

\section{METHODS}

The Present study was conducted at Government Raja Mirasudhar hospital, Thanjavur medical college, Thanjavur from October 2017 to October 2018.The efficacy of labetalol verses nifedipine in management of hypertensive disorders of pregnancy was studied. The study consisted of 100 antenatal patients with nonsevere preeclampsia after 20 weeks of gestational age. Gestational hypertension, severe preeclampsia, imminent eclampsia, eclampsia, chronic hypertension, heart diseases, haematological disorders, liver diseases, diabetes, renal diseases were excluded from the study. Informed consent was obtained. A complete history was taken, thorough clinical examination and investigations were done. Patients with blood pressure of 150/100 mm of $\mathrm{Hg}$ and above were started on antihypertensive drug.
The patients in Group A received tablet labetalol with a starting dose of $100 \mathrm{mg}$. Blood pressure was recorded 2nd hourly and the dose was increased by $100 \mathrm{mg}$ every 6 th hourly until adequate control was achieved. The next day the total dose required was divided and given as twice daily dosage. The same dose was continued thereafter.

In Group B, tablet nifedipine was started in the dose of 10 $\mathrm{mg}$, blood pressure was recorded 2nd hourly, dose increased by $10 \mathrm{mg}$ 6th hourly until adequate control was achieved. Total dose was divided as thrice daily dosage from the second day and the same dose continued thereafter.

Brachial artery blood pressure was checked with the patient in lateral recumbent position using calibrated mercury sphygmomanometer and appropriate cuff size. Korotkoff $\mathrm{V}$ was used to determine diastolic blood pressure. The blood pressure was monitored at $0,6,12$, 24, 48, 72 hours. The initial dosage of antihypertensive drug was observed; side effects if any associated with drug intake was noted.

\section{RESULTS}

100 cases were randomized to 50 cases of Nifedipine and 50 cases of labetalol each with matching age, parity, gestational age, blood pressure recordings, keeping these variables constant among these two divided groups through table 1 to 3 . Table 2 emphasizes the fact that preeclampsia is primarily a disorder of young primigravidae. From table 3 it is evident that most of the pregnant women in both the groups belonged to gestational age of 34 - 36 weeks. (Table 1) (Table 2) (Table 3).

Table 1: Distribution of cases age wise.

\begin{tabular}{|c|c|c|c|c|c|c|c|}
\hline \multirow{2}{*}{ Age } & \multicolumn{2}{|c|}{ Group A } & \multicolumn{2}{|c|}{ Group B } & \multicolumn{2}{|l|}{ Total } & \multirow{2}{*}{ Statistical Inference } \\
\hline & $\mathbf{N}=\mathbf{5 0}$ & $\%$ & $\mathbf{N}=\mathbf{5 0}$ & $\%$ & $\mathbf{N}=100$ & $\%$ & \\
\hline Below 20 years & 4 & 8 & 3 & 6 & 7 & 7 & \multirow{4}{*}{$\begin{array}{l}\mathrm{X}^{2}=0.385 \mathrm{df}=3 \\
\mathrm{P}=0.943>0.05 \\
\text { Not Significant }\end{array}$} \\
\hline 21 to 25 years & 26 & 52 & 25 & 50 & 51 & 51 & \\
\hline 26 to 30 years & 12 & 24 & 12 & 24 & 24 & 24 & \\
\hline 31 years and Above & 8 & 16 & 10 & 20 & 18 & 18 & \\
\hline
\end{tabular}

Table 2: Distribution of cases according to parity.

\begin{tabular}{|c|c|c|c|c|c|c|c|}
\hline \multirow{2}{*}{ Parity } & \multicolumn{2}{|c|}{ Group A } & \multicolumn{2}{|c|}{ Group B } & \multicolumn{2}{|l|}{ Total } & \multirow{2}{*}{ Statistical Inference } \\
\hline & $\mathbf{N}=\mathbf{5 0}$ & $\%$ & $\mathbf{N}=\mathbf{5 0}$ & $\%$ & $\mathbf{N}=\mathbf{1 0 0}$ & $\%$ & \\
\hline G1 & 26 & 52 & 25 & 50 & 51 & 51 & \multirow{4}{*}{$\begin{array}{l}\mathrm{X}^{2}=0.480 \mathrm{df}=3 \\
\mathrm{P}=0.923>0.05 \\
\text { Not Significant }\end{array}$} \\
\hline G 2 & 14 & 28 & 15 & 30 & 29 & 29 & \\
\hline G 3 & 7 & 14 & 8 & 16 & 15 & 15 & \\
\hline G 4 & 3 & 6 & 2 & 4 & 5 & 5 & \\
\hline
\end{tabular}

In Group A, majority of the patients required dosage between 200 and $400 \mathrm{mg}$ of labetalol and in Group B the commonly required dose was 20 - $30 \mathrm{mg}$ of nifedipine to achieve adequate control of blood pressure (Table 4) (Table 5). 
Table 3: Distribution of cases according to gestational age.

\begin{tabular}{|c|c|c|c|c|c|c|c|}
\hline \multirow{2}{*}{$\begin{array}{l}\text { Gestational age } \\
\text { (in weeks) }\end{array}$} & \multicolumn{2}{|c|}{ Group A } & \multicolumn{2}{|c|}{ Group B } & \multicolumn{2}{|l|}{ Total } & \multirow{2}{*}{ Statistical Inference } \\
\hline & $\mathbf{N}=\mathbf{5 0}$ & $\%$ & $\mathbf{N}=\mathbf{5 0}$ & $\%$ & $\mathrm{~N}=\mathbf{1 0 0}$ & $\%$ & \\
\hline 28 to 33 & 10 & 20 & 10 & 20 & 20 & 20 & \multirow{3}{*}{$\begin{array}{l}\mathrm{X}^{2}=0.000 \mathrm{df}=2 \\
\mathrm{P}=1.000>0.05 \\
\text { Not Significant }\end{array}$} \\
\hline 34 to 36 & 30 & 60 & 30 & 60 & 60 & 60 & \\
\hline Term & 10 & 20 & 10 & 20 & 20 & 20 & \\
\hline
\end{tabular}

Table 4: Distribution of cases according to required dosage of drug.

\begin{tabular}{|lll|}
\hline Dose $(\mathbf{m g})$ & Group A & \\
\hline 200 & $\mathbf{N}=\mathbf{5 0}$ & $\mathbf{\%}$ \\
\hline 300 & 17 & 34 \\
\hline 400 & 13 & 26 \\
\hline 500 & 11 & 22 \\
\hline 600 & 7 & 14 \\
\hline
\end{tabular}

Among the patients in Group A under labetalol, 14\% progressed to severe preelampsia and in Group B under nifedipine, $20 \%$ progressed to severe preeclampsia and the difference was not statistically significant (Table 6).
Table 5: Distribution of cases according to required dosage of drug.

\begin{tabular}{|lll|}
\hline Dose $(\mathbf{m g})$ & Group B & \\
\hline 20 & $\mathbf{N}=\mathbf{5 0}$ & $\mathbf{\%}$ \\
\hline 30 & 17 & 34 \\
\hline 40 & 13 & 26 \\
\hline
\end{tabular}

In Group A none of the patients developed any side effects due to the drug whereas in Group B $12 \%$ showed adverse reactions of the drug. The difference was statistically significant (Table 7). 86\% in Group A and $80 \%$ in Group B delivered at term and the difference was not statistically significant (Table 8).

Table 6: Progression to severe preeclampsia.

\begin{tabular}{|c|c|c|c|c|c|c|c|}
\hline \multirow{2}{*}{ Complication } & \multicolumn{2}{|c|}{ Group A } & \multicolumn{2}{|c|}{ Group B } & \multicolumn{2}{|l|}{ Total } & \multirow{2}{*}{ Statistical inference } \\
\hline & $\mathbf{N}=\mathbf{5 0}$ & $\%$ & $\mathbf{N}=\mathbf{5 0}$ & $\%$ & $\mathbf{N}=\mathbf{1 0 0}$ & $\%$ & \\
\hline Severe preeclampsia & 7 & 14 & 10 & 20 & 17 & 17 & $\begin{array}{l}X^{2}=0.870 \quad \mathrm{df}=2 \\
P=0.602>0.05 \\
\text { Not Significant }\end{array}$ \\
\hline
\end{tabular}

Table 7: Drug side effects.

\begin{tabular}{|c|c|c|c|c|c|c|c|}
\hline \multirow{2}{*}{ Drug Side Effects } & \multicolumn{2}{|c|}{ Group A } & \multicolumn{2}{|c|}{ Group B } & \multicolumn{2}{|l|}{ Total } & \multirow{2}{*}{ Statistical Inference } \\
\hline & $\mathbf{N}=\mathbf{5 0}$ & $\%$ & $\mathbf{N}=\mathbf{5 0}$ & $\%$ & $\mathbf{N}=100$ & $\%$ & \\
\hline Giddiness & 0 & 0 & 1 & 2 & 1 & 1 & \multirow{3}{*}{$\begin{array}{l}\mathrm{X}^{2}=11.383 \\
\mathrm{df}=3 \mathrm{P}=0.0490<0.05 \\
\text { Significant }\end{array}$} \\
\hline Palpitation & 0 & 0 & 2 & 4 & 2 & 2 & \\
\hline Headache & 0 & 0 & 3 & 6 & 3 & 3 & \\
\hline
\end{tabular}

Table 8: Distribution of cases according to gestational age at delivery.

\begin{tabular}{|c|c|c|c|c|c|c|c|}
\hline \multirow{2}{*}{$\begin{array}{l}\text { Gestational age at delivery } \\
\text { (in weeks) }\end{array}$} & \multicolumn{2}{|c|}{ Group A } & \multicolumn{2}{|c|}{ Group B } & \multicolumn{2}{|l|}{ Total } & \multirow{2}{*}{ Statistical Inference } \\
\hline & $\mathbf{N}=\mathbf{5 0}$ & $\%$ & $\mathbf{N}=\mathbf{5 0}$ & $\%$ & $\mathrm{~N}=100$ & $\%$ & \\
\hline 28 to 33 & 3 & 6 & 4 & 8 & 7 & 7 & \multirow{3}{*}{$\begin{array}{l}X^{2}=0.651 \text { df }=2 \\
P=0.722>0.05 \\
\text { Not Significant }\end{array}$} \\
\hline 34 to 36 & 4 & 8 & 6 & 12 & 10 & 10 & \\
\hline Term & 43 & 86 & 40 & 80 & 83 & 83 & \\
\hline
\end{tabular}

In Group A, 24\% delivered by caesarean section and in Group B, 30\% needed caesarean section and the difference was not statistically significant (Table 9).

In group A 43 were term babies and in group B 40 were term babies (Table 10).
In Group A, among the $14 \%$ of preterm babies delivered, $6 \%$ had birth weight $<2 \mathrm{~kg}$ and the remaining $8 \%$ weighed between $2-2.5 \mathrm{~kg}$. In group B, among $20 \%$ preterm babies, $8 \%$ had birth weight $<2 \mathrm{~kg}$ and the remaining $12 \%$ weighed between $2-2.5 \mathrm{~kg}$. In both the groups, all term babies had a birth weight of $>2.5 \mathrm{~kg}$ (Table 11). 
In group A, 48 patients $(96 \%)$ did not require any antihypertensive in the puerperium and in group B, 46 patients (92\%) were not on anti-hypertensive after delivery (Table 12).

Table 9: Distribution of cases according to mode of delivery.

\begin{tabular}{|c|c|c|c|c|c|c|c|}
\hline \multirow{2}{*}{ Mode of delivery } & \multicolumn{2}{|c|}{ Group A } & \multicolumn{2}{|c|}{ Group B } & \multicolumn{2}{|l|}{ Total } & \multirow{2}{*}{ Statistical Inference } \\
\hline & $\mathbf{N}=\mathbf{5 0}$ & $\%$ & $\mathbf{N}=\mathbf{5 0}$ & $\%$ & $\mathrm{~N}=100$ & $\%$ & \\
\hline Vaginal & 38 & 76 & 35 & 70 & 73 & 73 & \multirow{3}{*}{$\begin{array}{l}X^{2}=0.464 \text { df }=2 \\
P=0.793>0.05 \\
\text { Not Significant }\end{array}$} \\
\hline Emergency CS & 7 & 14 & 9 & 18 & 16 & 16 & \\
\hline Elective CS & 5 & 10 & 6 & 12 & 11 & 11 & \\
\hline
\end{tabular}

Table 10: Distribution of cases according to neonatal outcome.

\begin{tabular}{|llllllll|}
\hline $\begin{array}{l}\text { Neonatal } \\
\text { outcome }\end{array}$ & Group A & & Group B & Total & & Statistical Inference \\
\hline Pre term & $\mathbf{N}=\mathbf{5 0}$ & $\mathbf{\%}$ & $\mathbf{N = 5 0}$ & $\mathbf{\%}$ & $\mathbf{N = 1 0 0}$ & $\mathbf{\%}$ & $\mathrm{X}^{2}=0.638 \quad \mathrm{df}=1$ \\
\hline Term & 43 & 14 & 10 & 20 & 17 & 17 & $\begin{array}{l}\mathrm{P}=0.424>0.05 \\
\text { Not Significant }\end{array}$ \\
\hline
\end{tabular}

Table 11: Distribution of cases according to birth weight of babies.

\begin{tabular}{|c|c|c|c|c|c|c|c|}
\hline \multirow{2}{*}{ Birth weight } & \multicolumn{2}{|c|}{ Group A } & \multicolumn{2}{|c|}{ Group B } & \multicolumn{2}{|l|}{ Total } & \multirow{2}{*}{ Statistical Inference } \\
\hline & $\mathbf{N}=\mathbf{5 0}$ & $\%$ & $\mathbf{N}=\mathbf{5 0}$ & $\%$ & $\mathbf{N}=\mathbf{1 0 0}$ & $\%$ & \\
\hline$>2.5 \mathrm{~kg}$ & 43 & 86 & 40 & 80 & 83 & 83 & \multirow{3}{*}{$\begin{array}{l}\mathrm{X}^{2}=0.651 \quad \mathrm{df}=2 \\
\mathrm{P}=0.722>0.05 \\
\text { Not Significant }\end{array}$} \\
\hline 2 to $2.5 \mathrm{~kg}$ & 4 & 8 & 6 & 12 & 10 & 10 & \\
\hline$<2 \mathrm{~kg}$ & 3 & 6 & 4 & 8 & 7 & 7 & \\
\hline
\end{tabular}

Table 12: Neonatal admissions.

\begin{tabular}{|c|c|c|c|c|c|c|c|}
\hline \multirow{2}{*}{$\begin{array}{l}\text { Neonatal } \\
\text { Admission }\end{array}$} & \multicolumn{2}{|c|}{ Group A } & \multicolumn{2}{|c|}{ Group B } & \multicolumn{2}{|l|}{ Total } & \multirow{2}{*}{ Statistical Inference } \\
\hline & $\mathbf{N}=\mathbf{5 0}$ & $\%$ & $\mathbf{N}=\mathbf{5 0}$ & $\%$ & $\mathbf{N}=\mathbf{1 0 0}$ & $\%$ & \\
\hline Yes & 4 & 8 & 5 & 10 & 9 & 9 & $\begin{array}{l}\mathrm{X}^{2}=1.111 \text { df }=2 \\
\mathrm{P}=0.132>0.05 \\
\text { Not Significant }\end{array}$ \\
\hline
\end{tabular}

\section{DISCUSSION}

Hypertensive disorders complicates only 5-10\% of pregnancies but continues to be major health care related problem in pregnant women even after advancement in the field of medical sciences.

Our study showed that younger age of pregnant women (58\%) might have contributed to a greater frequency of preeclampsia. In a study by Ganesh SK et al, risk factors for preeclampsia were studied and the common age group at diagnosis was between 21 and 30 years. ${ }^{4}$ Another study conducted by Yadav et al, also concluded that the incidence of preeclampsia is greater when the age of pregnant women was less than 25 years. ${ }^{5}$

Our study also concluded that primiparous (51\%) are at more risk of developing preeclampsia. Sibai and Cunningham reviewed a number of worldwide studies and concluded that the incidence of pre-eclampsia in nulliparous was more than that for multiparous. ${ }^{6}$

In our study, both the groups had good control of blood pressure thereby proving that the two drugs, labetalol and nifedipine were equally efficacious. This result is consistent with a meta analysis by Peter Von Dadelszen et al, and with the study by Bharathi et al, where they have proved that both the drugs are effective, safe and rapid in their onset of action. ${ }^{7,8}$

In contrary to this study, Patel NK et al, have proved that labetalol has better efficacy than nifedipine in nonsevere preeclampsia. $^{9}$

In the same study by Bharathi et al both the drugs had side effects but they were higher in nifedipine group. Similar to our study the most common side effect with nifedipine was headache. 
In our study, there was no significant difference on the gestational age at delivery,on the disease progression and on the fetomaternal outcome between the two groups. This is consistent with the results of the study by Waterman EJ et al, which showed that there are no detrimental effects on uteroplacental or fetal hemodynamics with the use of labetalol and nifedipine in pregnancy. ${ }^{10}$ The same study proved no detrimental effects on neonatal outcome including birth weight.

In contrary to this study, Patel NK et al, showed that the neonatal outcome was better with labetalol as there was lower incidence of respiratory distress of newborn. ${ }^{9}$

\section{CONCLUSION}

In this study, none of the patients developed life threatening complications of preeclampsia like eclampsia, pulmonary edema, HELLP syndrome, acute kidney injury, cerebro vascular accidents and postpartum collapse. There was no maternal mortality in this study.

\section{Funding: No funding sources}

Conflict of interest: None declared

Ethical approval: The study was approved by the Institutional Ethics Committee

\section{REFERENCES}

1. Hypertensive Disorders In: Williams Obstetrics, 25th ed, New York, NY: McGraw-Hill. 2018:40:711.

2. Odigboegwu O, Pan LJ, Chatterjee P. Use of antihypertensive drugs during preeclampsia. Front Cardiovasc Med. 2018;5:50.

3. Lakshmi KV, Lakshmi K. Labetalol Vs Nifedipine in treatment of pregnancy induced hypertension. Int $\mathbf{J}$ Sci Res. 2016:5(12):10-1.

4. Ganesh SK, Unnikrishnan B, Nagaraj K, Jayaram S. Determinants of pre-eclampsia: A case-control study in a district hospital in South India. IJCM. 2010;35(4):502-5.

5. Yadav S, Saxena U, Yadav R, Gupta S. Hypertensive disorders of pregnancy and maternal and foetal outcome: a case controlled study. J Indian Med Assoc. 1997;95(10):548-51.

6. Sibai BM, Cunningham FG. Prevention of preeclampsia. In Lindheimer MD, Roberts JM, Cunningham FG editors: Chesley's hypertensive Disorders of Pregnancy. 3rd edition, Elsevier, NewYork. 2009;215.

7. Von Dadelszen P, Ornstein MP, Bull SB, Logan AG, Koren G, Magee LA. Fall in mean arterial pressure and fetal growth restriction in pregnancy hypertension: a meta-analysis. Lancet. 2000;355:8792.

8. Bharathi KN, Prasad KVSRG, Jagannath Pairu, Naik BC. Comparison of anti hypertensive efficacy of labetol, nefedipine and methyl dopa in pregnancy induced hypertension. Pharmacol Online. 2009;3:670-8.

9. Patel NK, Gadhavi M, Gorasia D, Pandya MR. Comparative evaluation of antihypertensive drugs in the management of pregnancy-induced hypertension. Int J Basic Clin Pharmacol. 2012;1(3):174-7.

10. Waterman EJ, Magee LA, Lim KI, Skoll A, Rurak D, von Dadelszen P. Do commonly used oral antihypertensives alter fetal or neonatal heart rate characteristics? A systematic review. Hypert Pregn. 2009:155-69.

Cite this article as: Rose DT, Jeyarani P. Comparative study of labetalol and nifedipine in management of nonsevere preeclampsia and its fetomaternal outcome. Int $\mathbf{J}$ Reprod Contracept Obstet Gynecol 2019;8:2034-8. 